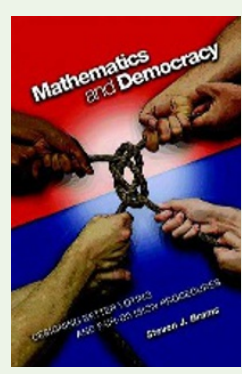

The forthcoming US presidential election has spawned books about the science of voting. Political decisions can be made more democratic using social choice and game theory, allowing voters to express their preferences and enabling public goods to be divided fairly, explains Steven J. Brams in Mathematics and Democracy: Designing Better Voting and Fair-Division Procedures (Princeton Univ. Press, 2008). Brams has also updated his classic 1978 book, The Presidential Election Game (A. K. Peters, 2008), which dissects presidential campaign strategies.

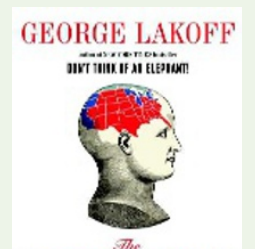

POLITICAL MIND

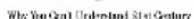

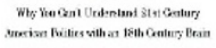

Engaging emotions is key to winning votes and political arguments, argues George Lakoff in The Political Mind: Why You Can't Understand 21st-Century American Politics with an 18th-Century Brain (Viking, 2008). He suggests that fact-laden Democrat campaigns could benefit from using emotionally loaded phrases such as 'tax relief' or 'war on terror'.

\section{In Gaming the Vote: Why Elections} Aren't Fair (and What We Can Do About It) (Hill \& Wang, 2008), William Poundstone seeks out the fairest voting systems and explains why the most popular candidate may not always win.

Facing decisions on topics from nuclear terrorism to climate change, the new president might consult Richard A. Muller's Physics For Future Presidents: The Science Behind the Headlines (W. W. Norton, 2008). Or he might turn to Joseph S. Nye's The Powers to Lead (Oxford Univ. Press, 2008) for tips on how to mimic the best leadership styles.

And for perking up that speech, he might consider reading Tippecanoe and Tyler Too: Famous Slogans and Catchphrases in American History (Chicago Univ. Press, 2008) by Jan R. Van Meter, for the stories behind 50 famous phrases, such as "nice guys finish last". telephoning individual customers, but in 1936 the speaking clock was introduced. Known as TIM, it gave ordinary people immediate access to standardized time. In its first year, TIM took 20 million calls in London alone, from customers who dialled up to hear the recorded voice of Ethel Cain, an exchange operator picked out at an audition after her mellifluous reading of a poem by John Milton. Although there have been several other human announcers since then, this telephonic clock still speaks on, coexisting with more recent timekeepers that continuously set themselves automatically. As Rooney concludes, "New isn't necessarily better, it's just different ... stuff endures."

Rooney has the rare gift of combining the obsessiveness of an academic sleuth with the fluency of a detective novelist: not many people would attempt to write entertainingly about how the dot of the Morse code became the pip of a time signal. With its small format and subdued cover, Rooney's book superficially resembles Michael Lemonick's book The Georgian Star, which also uses an engaging and informative style to present a combination of history and science. Like Rooney's, Lemonick's subjects are two close relatives in this case, the siblings William and Caroline Herschel - who also relied on an accurate scientific instrument, a telescope. There are three Georgian 'stars' in this relationship: two astronomers, here cast in heroic mode, and the planet Uranus, originally named 'George's Star' by William Herschel to gratify King George III of Great Britain and Ireland.

The Herschels worked together on the massive telescopes that helped William to become famous for his discovery of a new planet and for his work on nebulae. Disconcertingly for modern readers with egalitarian aspirations, Caroline seems to have colluded in her own marginalization, protesting that "I am nothing, I have done nothing ... a welltrained puppy-dog would have done as much".
Caroline's reputation improved towards the end of the twentieth century, when feminists commemorated her as the first woman to discover a new comet, even though this is of little scientific significance when compared with the collaboration with her brother and the star catalogue that she laboriously compiled. Caroline features prominently throughout Lemonick's book, although by the epilogue she has been reduced to a cranky old woman who helps her nephew, the Victorian astronomer John Herschel, to assume the mantle of genius passed down from his father.

Whereas Rooney presents his own original research in an accessible way, Lemonick behaves more like a journalist providing a colourful version of well-known historical and scientific material. His major source of information is the astronomy expert Michael Hoskin of the University of Cambridge, UK, and Lemonick repeatedly portrays himself as a reporter transmitting the privileged conversations he enjoyed in Hoskin's Cambridge home. Hoskin is indeed a leading authority on the Herschels, but Lemonick unsceptically attributes to him the ability "to go beyond the straightforward facts ... and to understand their complex and remarkable personalities". At the end of The Georgian Star, Lemonick approvingly reproduces William Herschel's boast that, thanks to his telescope, "I have looked further into space than ever human being did before me." In contrast with this eulogy of a powerful instrument, Rooney's closing remark is that Ruth Belville "provided what no electrical wire could: the personal touch". Because she supplied what her customers wanted, her service outlasted sophisticated inventions.

Patricia Fara is the senior tutor of Clare College, University of Cambridge, Cambridge CB2 1TL, UK. Her forthcoming book is Science: A Four Thousand Year History. e-mail:pf10006@cam.ac.uk

\title{
No species is an island
}

\section{The Loom of Life: Unravelling Ecosystems by Menno Schilthuizen \\ Springer: 2008.220 pp. $£ 37.50$}

In the summer of 1966, Harvard biologist Edward O. Wilson and his student Daniel Simberloff undertook a classic ecology experiment in Florida. They identified a number of minuscule mangrove islands, took a census of their mostly insect fauna, and then paid an exterminator to kill all the animals on the islands with methyl bromide. Observing the islets as they became repopulated, they found that, after eight months, nearly all had regained the same number of species as they had hosted before the extermination. But most of these inhabitants were not of the same species as before.

The scientists' interventions confirmed the theory of island biogeography that Wilson and Robert MacArthur had published some years 